\title{
Physical Exam Performed
}

National Cancer Institute

\section{Source}

National Cancer Institute. Physical Exam Performed. NCI Thesaurus. Code C113376.

An indication or description that a subject physical examination test has occurred. 